\title{
Industry 4.0 in Electronics and Automotives Sectors and Its Prospect for Indonesia's Economic Diplomacy
}

\author{
Sylvia Octa Putri \\ Department of International Relations \\ Universitas Komputer Indonesia \\ Bandung, Indonesia \\ sylvia.octa.putri@email.unikom.ac.id
}

\author{
Galih Ginanjar \\ Center for Material and Technical Product (B4T) \\ Ministry of Industry of The Republic of Indonesia \\ Bandung, Indonesia \\ galih@kemenperin.go.id
}

\begin{abstract}
This paper demonstrates how the Industry 4.0 which is to digitalize and connect the industry can unlock the country from several economic challenges and have potentials contribute for Indonesia's economic diplomacy achievement. The research method was a qualitative approach, which data collection technique was conducted through literature review and interviews with informants, including practitioners and experts in related fields. The result of this paper shows Industry 4.0 roadmap through Making Indonesia 4.0 increasingly connecting the digital world with the industrial sector and changing the Indonesia economy to become a digital economy. Making Indonesia 4.0 roadmap in electronic and automotive sectors can contribute greatly to the export growth, opening up new markets and attracting investment in Indonesia. Making Indonesia 4.0 roadmap enhancing the competitiveness of national industries and contribute for Indonesia's economic diplomacy achievement as the top 10th world, economic powers and the welfare of society.
\end{abstract}

Keywords - Industry 4.0, Indonesia Economic Diplomacy, Electronics, Automotives, Export, Investment

\section{INTRODUCTION}

Industry 4.0 is the term from the 4th Industrial Revolution which is was originally developed in Germany in 2011 that motivated by Germany's interest as a leading country in the manufacturing industry. [1] Industry 4.0 includes a variety of advanced technologies such as artificial intelligent, internet of things, robotics, wearable and 3D printing.

Industry 4.0 has tremendous potentials not only in industrial development but also in changing aspects of human life. In Indonesia the phenomenon of Industry 4.0 provides an opportunity to revitalize Indonesia's manufacturing sector. Through Roadmap of "Making Indonesia 4.0", the Government of Indonesia focuses on five main sectors initiative in implement this technology, are following (i) the food and beverage sector, (ii) textiles and clothing, (iii) automotive, (iv) chemical and (v) electronics. The implementation of Industry 4.0 in these five sectors is considered to contribute and increase global competitiveness and open the global export market share.
Diplomacy has an important role in this matter. In addition to the need for strategies to accelerate the development of the national manufacturing industry, a diplomatic strategy is also needed to promote cooperation and investment opportunities in related fields to accelerate the achievement of Indonesia's vision of becoming the 10 largest economies in the world. [2]

Research or studies on the 4.0 Industry phenomenon in Indonesia have previously been studied by Hoedi Prasetyo and Wahyudi Sutopo where Industry 4.0 has a positive impact on the country's economy, offers many benefits and those challenges that must be faced such as technological, economic, limited human resources, political conditions and the company's reluctance to implement technology. This research further emphasizes that the effort to realize Industry 4.0 is carried out through applied research and experimentation in the real industry. [1] The same thing also expressed by Andi Nur Bau Massepe in his article entitled "Making 4.0 Indonesia, Our New Industry Act" which emphasizes the existence of a research center will encourage the emergence of innovative products, strengthen competitiveness in the regions, encourage down streaming of research and technology results to be utilized by industry players. [3]

Venti Eka Satya also conducted a study on Industry 4.0 in Indonesia regarding Indonesia's Strategy in facing the Industry 4.0. Venti stated that Indonesia needs to prepare strategic steps in building a globally competitive manufacturing industry, where she emphasize more on anticipatory strategies against various possibilities which will have a negative impact on the national economy. This Industry will disrupt conventional business and reduce the demand for labor. For this reason, a legal mechanism is needed that will regulate the implementation of the new system, by encouraging the role of the DPR as a legislative institution. [4]

The Center for Economic and Public Policy Studies, Gadjah Mada University published an article reviewing the Industrial Revolution, 4.0, where industry 4.0 is believed to increase the productivity of the manufacturing industry as a result of a survey conducted on the leaders of 300 leading companies in Southeast Asia concerning the effectiveness of Industry 4.0. Building human capital to accompany the pace of infrastructure development in Indonesia is a priority [5] 
The research that examines diplomacy and industry was carried out by Rizki Rahmadini Nurika, although she did not study specific on Indonesian 4.0 in Indonesia, in her thesis Rizky revealed the existence of international relations actors, namely foreign mining companies in the development of the bauxite smelter industry in Indonesia which was produced by the role of commercial diplomacy in the form of investment promotion bauxite smelter. The investment promotion of bauxite smelters can be realized because the government and local mining companies have an interest in the realization of the development of bauxite smelters in Indonesia. The urgency in this study is that the government does support activities through its diplomatic means to help achieve these goals. [6]

Previous research believes that Industry 4.0 in Indonesia will increase global competitiveness, increase productivity, but unfortunately does not explore in detail the potential, prospects or opportunities that can be utilized to achieve these goals, but only limited to discussing industry 4.0 development strategies in applied research, local or domestic industrial readiness and legal mechanisms in its application, This is understandable because the 4.0 industry has just launched its Roadmap. While research on discussing diplomacy and industry is still rare, because there are still many who sees this phenomenon as a different field or sector. Whereas in fact the success of Industry 4.0 is supported and crossed many sectors. For this purpose the objectives of this research papers is to contribute ideas in the implementation of Industry 4.0 has deep potential in Indonesian economic diplomacy, because it increasing global competitiveness and opening the global export market share. This research is limited to the Electronics and Automotive sectors, which is one of the priority sectors of Industry 4.0 through Making Indonesia 4.0.

\section{METHOD}

To support the validity of the data, this study using qualitative research methods by collecting data through literature studies and interviews. Literature study explores various information in books, scientific journals, newspapers, magazines, and sources of information from articles and news through websites / websites on the internet. Other data collection techniques are through interviews. This technique is used to obtain in-depth data from informants as the authorities and opinions of experts who have the capacity regarding to research matter.

\section{RESULTS}

\section{A. Industry Strategy 4.0 in the Roadmap "Making Indonesia $4.0^{\prime \prime}$}

The Indonesian government through the Ministry of Industry has prepared an initiative "Making Indonesia 4.0" to implement the strategy and Roadmap for Industry 4.0 in Indonesia. This roadmap involves various stakeholders, ranging from government institutions, industry associations, business actors, technology providers, and research and education institutions. Road Map Making Indonesia 4.0 provides clear direction and strategy for the movement of Indonesian industry in the future, including in 5 (five) sectors that are the focus and 10 (ten) national priorities in an effort to strengthen Indonesia's industrial structure.
The 10 (ten) priorities include (i) Improving the flow of goods and materials, (ii) Redesigning industrial zones, (iii) Accommodating sustainability standards, (iv) Empowering MSMEs, (v) Building a national digital infrastructure, (vi) Attract foreign investment, (vii) Improve the quality of human resources, (viii) Development of innovation ecosystems, (ix) Incentives for technology investment, and (x) Harmonization of rules and policies.

While the 5 (five) main sectors that became the focus were (i) food and beverages, (ii) textiles and clothing, (iii) automotive, (iv) chemistry, and (v) electronics. This sector was chosen as the focus after going through an evaluation of economic impact and implementation feasibility criteria that included measures of GDP, trade, potential impacts on other industries, the amount of investment, and the speed of market penetration. The five sectors are built with the aim of regional competitiveness, namely in ASEAN. [2]

Especially in the Electronics and Automotive Sector which is the focus of this paper, where the Electronic Sector aims to develop the capabilities of domestic industry players. Indonesia's electronic industry is still developing and is dependent on imported components and local production from global players. Local production is still concentrated in simple assembly and has not been involved in many processes that are value added. Electronic strategy 4.0 is: (i) Attract leading global players with attractive incentive packages and (ii) develop capabilities in producing value-added electronic components. (iii) Developing the ability of the domestic workforce through intensive training and attracting foreign workers in certain fields that are needed and (4) developing competent domestic industry players who are competent to encourage continued innovation and accelerate technology transfer.

Whereas in the Automotive Sector aims to become a leading player in the export of Internal Combustion Engine (ICE) and Electric Vehicle (EV). Supported by the domestic market and strong investment from various leading automotive companies, Indonesia wants to become the largest car producer in ASEAN. Indonesia is currently the second largest automotive exporter in the region, although vehicle production still depends on imports of raw materials (metals and chemicals) and other important electronic components. In addition, as the penetration of world electric vehicles (EV) is expected to increase sharply in 2020.

Indonesia will focus on supporting the development of EV. Automotive 4.0 strategies include: Increasing local production, in terms of (i) volume and (ii) efficiency in the production of raw materials and important components through technology adoption and infrastructure development, such as the development of integrated industrial zones and a more efficient logistics platform. (iii) Collaborate with world OEM companies to increase exports, focusing on multi-purpose vehicles (MPV), low-cost environmentally friendly vehicles, and sport utility vehicles (SUVs). (iv) Building an ecosystem for the EV industry, starting with the ability to manufacture electric motorbikes, then developing the ability of electric cars based on the inevitable adoption of EV in the future. [2]

\section{B. Indonesia's Economic Diplomacy}

In line with Trisakti and Nawacita, and the National Medium Term Development Plan 2014-2019 (RPJMN), 
Indonesia's foreign policy for the next 5 (five) years will be carried out based on the principle of free-active foreign policy based on national interests and strengthening national identity. as a maritime country. In implementing the policy, the RPJMN mandates the synergy between political diplomacy and economic diplomacy. This is because Indonesian diplomacy is expected to contribute to national economic development, one of which is measured through economic growth which reaches 6-8\% per year. Economic diplomacy is expected to help achieve Indonesia's economic growth target towards world economic power.

In accordance with the 2015-2019 RI Ministry of Foreign Affairs Strategic Plan (Renstra), the Ministry of Foreign Affairs will adjust strategies and strengthen economic diplomacy to support economic growth that has an impact on the people and national economic independence. During this period, economic diplomacy with major market countries will be focused on removing non-tariff barriers, while with prospective market countries, efforts will be made to open new markets or prospective markets in various regions.

The Economic Diplomacy Working Group (Pokja) formed by the Indonesian Ministry of Foreign Affairs at the beginning of 2015 aims to support the achievement of the vision and mission of President Jokowi and Vice President Jusuf Kalla for the period 2014-2019 in the economic field which is Indonesia's diplomacy priority and one of the pillars supporting national economic independence and give the greatest contribution to the welfare of the people.

The Economic Diplomacy Working Group has several tasks, (i) Strengthening the implementation of the duties of the Indonesian Ministry of Foreign Affairs and RI representatives to support the achievement of economic targets and development cooperation determined by the relevant Ministries or agencies. (ii) Provide more effective responses to business opportunities, development cooperation and inquiry submitted by the Indonesian Representative and help coordinate the handling of issues / problems. (iii) Encourage further business opportunities and development cooperation to Ministries or Institutions, Regional Governments, KADIN or related business associations as stakeholders and help synergize and coordinate the implementation of promotional activities abroad. (iv) Monitor responses to business opportunities (inquiry from RI representatives) and development cooperation with stakeholders. (v) Facilitating match-making between trading partners and business agreements and development cooperation. [7] Although the Indonesian Ministry of Foreign Affairs Working Group set three main indicators in achieving economic diplomacy, namely Trade, Tourism and Investment (TTI). In our research we see that the achievement of Indonesia's economic diplomacy can also be achieved through Making Indonesia 4.0. So it needs to be designed a strategy in economic diplomacy itself. Some countries such as China and Germany develop innovative diplomacy as a strategy to achieve economic diplomacy through an innovative partnership in the form of cooperation in high-tech Industry 4.0 projects. Innovative diplomacy is China's strategy in utilizing German's advanced manufacturing technology to improve the manufacturing industry and China's economy.[8]

\section{DISCUSSION}

4.1 Making Indonesia 4.0 in the Electronics and Automotive Sectors and Prospects for Indonesian Economic Diplomacy

The successful Making Indonesia 4.0 implementation is expected to boost real GDP growth by 1-2 percent per year, so GDP growth per year will increase from baseline by 5 percent to 6-7 percent in the period 2018-2030, where manufacturing industries contribute $21-26$ percent of GDP by 2030 . GDP growth is driven by a significant increase in net exports, where Indonesia is expected to reach 5-10 percent of the ratio of net exports to GDP in 2030. In addition to the increase in productivity, Making Indonesia 4.0 promises to open jobs as many as 7-19 million, both in the manufacturing and nonmanufacturing sectors, by 2030 as a result of greater export demand.

With the implementation of Industry 4.0, the global economic trend has turned into a digital economy that leads to sharing economy which is characterized by two collaborations, namely consumption collaboration and production collaboration. Consumption collaboration brings together owners and borrowers with a minimum transaction cost on certain technology platforms and makes money from underused assets. We can see examples of this consumption collaboration in industry practices such as Airbnb, Uber, Grab, Gojek, etc. In addition there are also collaborative productions which are characterized by the phenomenon of individualization of mass products where there are no more differences between producers and consumers. Everyone can become "prosumer" (producer and consumer at one time. [9] In Southeast Asia, it can be seen in how rapidly ICT and Industry 4.0 has been adopted in booming industries such as tourism (such as air ticket booking, hotel booking, restaurant booking), design, internet and phone banking, call centers, etc. With a smart approach to industry, the region has the opportunity to leapfrog ahead. [10]

No exception in Indonesia, Making Indonesia 4.0 also will slowly change the face of Indonesia's economy into a digital economy. With Industry 4.0 the government will build industrial zones that encourage infrastructure and transportation development that have a positive impact on economic and community development. The existence of geoeconomic changes in the world from the west to Asia and Indonesia's contribution to global economic growth by 2.5 percent and ranked 4th in the contribution of the manufacturing industry sector to GDP at 22 percent. then Making Indonesia 4.0 will be a strong factor in Indonesia's achievement as the top 10 of the world economic power, and economic diplomacy is an important instrument in its achievement.[2]

Thus the successful implementation of Industry 4.0 through the Roadmap "Making Indonesia 4.0" requires synergies and integration of achievement strategies by the Ministry of Industry and related institutions such as Ministries, Regional Governments, Companies, Investors, Community Industry Actors, Academics, Institutions research and other related institutions. Especially in increasing the nation's competitiveness and increasing global market share, Indonesia's economic diplomacy will contribute greatly to achieving this. 
With the establishment of the Automotive 4.0 strategy, we believe it will stimulate strategies for economic diplomacy achievement such as (i) Optimizing the functions of the Indonesian Embassy in the ASEAN region and globally through the placement of Industrial Attaches and Techdiplomat's role in promoting Making Indonesia 4.0 (ii) Mapping of markets traditional and prospective in the ASEAN region and globally to increase the export share of the Indonesian automotive industry. (iii) Facilitate overseas promotions and exhibitions in the field of high-tech industry and Industry 4.0. (iv) Disseminating and socializing the export strategies and educating local companies and small industries regarding the stages of transformation and adoption of industrial technology 4.0 so that the money value is high and meets international standards, through discussion forums and meetings (v) Encouraging business cooperation opportunities with foreign automotive companies and investments (vi) Reaching opportunities for senior expert services assistance that funded by developed countries such as vocational training / workshops to transfer knowledge and build ecosystems for industry 4.0 in the automotive sector (vii) domestic industry promotion in overseas, in order to improve the competitiveness of the nation's industry. (viii) Collaborating and partnerships with foreign countries in the field of industry 4.0 (ix) With the transformation of global economic trends into digital economy, digital diplomacy and cyber diplomacy are also contribute to the success of Industry 4.0

Whereas in the Electronic Sector, we also believe that Electronic Strategy 4.0 will stimulate strategy Indonesia's economic diplomacy achievement such as (i) attracting foreign investors, especially leading companies in the electronics sector for technology transfers and investment through promotions and exhibitions. (ii) Strengthening cooperation and collaborating educational and research partnership opportunities through scholarships education, expert services assistance, grants from foreign countries to improve the ability of engineers in Indonesia. (iii) Facilitating programs to encourage producers of superior products or components of domestic electronic products to expand in developing countries. [11-17]

\section{CONCLUSION}

Making Indonesia 4.0 through the automotive and electronic sectors sustains national independence, improves the competitiveness of the nation's industry and opens up market share for global exports and contributes to the achievement of Indonesia's economic diplomacy as the top $10^{\text {th }}$ world economic powers and the welfare of society.

\section{ACKNOWLEDGMENT}

We would like to take this opportunity to thank to Center for Material and Technical Product (B4T), Ministry of Industry of The Republic of Indonesia, ICOBEST 2018 UNIKOM Organizing Committee and following reviewers of the original abstracts and the papers submitted for consideration in this conference.

\section{REFERENCES}

[1] Hoedi Prasetyo, Wahyudi Sutopo, "Industri 4.0: Telaah Klasifikasi Aspek dan Arah Perkembangan Riset", 2018, pp 18 19

[2] "Making Indonesia 4.0", Ministry of Industry, The Republic of Indonesia. accessed through http://www.kemenperin.go.id/download/18384

[3] Andi Nur Bau Massepe, "Making 4.0 Indonesia", Babak Baru Industri Kita", 2018, accessed through https://www.researchgate.net/publication/325683480

[4] Venti Eka Satya, "Strategi Indonesia Menghadapi Industri 4.0" dalam Info Singkat : Kajian Singkat Terhadap Isu Aktual Dan Strategis, Vol. X, No. 09///Puslit/Mei/2018, pp 19-23

[5] "Revolusi Industri 4.0", Pusat Studi Ekonomi dan Kebijakan Publik, 2018, Universitas Gadjah Mada, accessed through https://psekp.ugm.ac.id/2018/04/10/revolusi-industri-4-0/

[6] Rizki Rahmadini Nurika, "Peran Diplomasi Komersial dalam Pengembangan Industri Smelter Bauksit di Indonesia", Electronic Theses and Dissertations (ETD), Gadjah Mada University, 2015, pp 126-129

[7] Tabloid Diplomasi No.102 Tahun X, 2017, Ministry of Foreign Affairs pp. 5-6.

[8] Bai Shi,"Innovative Diplomacy : PM's visit enriches China's cooperation with European partners", Beijing Review, 2014 accessed through http://www.bjreview.com.cn/print/txt/201410/20/content_645612.htm

[9] Presentation by Head of Industrial Research and Development Agency / Badan Penelitian dan Pengembangan Industri (BPPI), Ministry of Industry, The Republic of Indonesia

[10] Yanfei Li, "Industry 4.0 and Energy 4.0 for Southeast Asia", The Diplomat, 2015, accessed through https://thediplomat.com/2015/05/industry-4-0-and-energy-4-0for-southeast-asia/

[11] "Industry 4.0 for Smart Sustainable Cities In Latin America", accessed through https://moderndiplomacy.eu/2018/05/31/industry-4-0-for-smartsustainable-cities-in-latin-america/

[12] "Industry 4.0 : Are You Ready?" in Delloite Review, Delloite Insights, 2018, accessed through https://www2.deloitte.com/content/dam/Deloitte/de/Documents/h uman-capital/DI_Deloitte-Review-22.pdf

[13] Kagermann, H., Anderl, R./Gausemeier, J.Schuh, G.Wahlster, W. (Eds.): "Industrie 4.0 in a Global Context: Strategies for Cooperating with International Partners" Acatech Study, Munich: Herbert Utz Verlag . 2016 accessed through https://www.plattformi40.de/I40/Redaktion/EN/Downloads/Publikation/industrie-40-ina-global-context.pdf?__blob=publicationFile \&v $=1$

[14] Žikica Milošević, "Industry 4.0 - A New Era Of Production" 2016 accessed through http://www.diplomacyandcommerce.rs/industry-4-0-a-new-eraof-production/

[15] "Russia 4.0: The Fourth Industrial Revolution as a Driver of Global Competitiveness", 2017, accessed through http://tass.com/sp/948066

[16] Wolfgang Schroeder, "Germany's Industry 4.0 Strategy Rhine Capitalism in the Age of Digitalisation", 2016, accessed through https://www.feslondon.org/fileadmin/user_upload/publications/files/FESLondon_Schroeder_Germanys-Industrie-40-Strategy.pdf

[17] Henning Banthien, "Implementation of an Industry 4.0 Strategy : The German Plattform Industrie 4.0", 2017, accessed through https://ec.europa.eu/digital-singlemarket/en/blog/implementation-industry-40-strategy-germanplattform-industrie-40 